\title{
BETTY FREUND: A NURSE IN FRANCE - Part II
}

\section{Compiled and edited by Betty Hugo*}

Accounts of Betty's death and funeral service, newspaper cuttings, and a copy of the programme issued at a Memorial Service held in Cape Town in 1925.

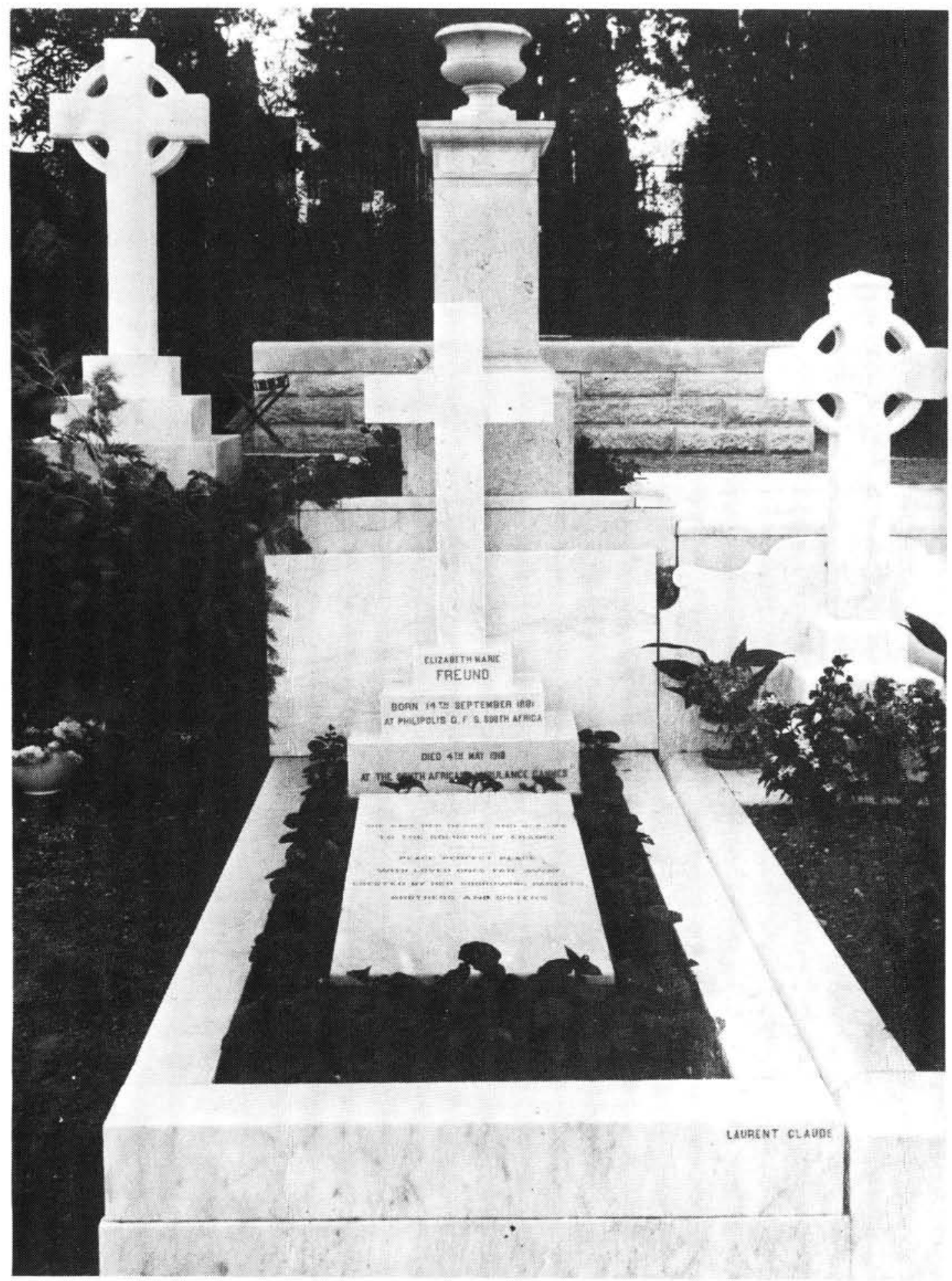

Betty Freund's grave (in the Protestant Section of the Cannes Cemetery) 


\section{THE CABLE}

16th May, 1918

Dear Sir,

I have to confirm my cable of the 13th instant reading as follows:

"163. Communicate the following to Martin begins Deeply regret to inform you death 4th May Sister Freund full particulars by mail convey Committee's sympathy to relatives French Government have awarded her gold Medaille des Epidemies in recognition of services rendered Beau Rivage Villa Felicie March average 9727 respectively. - Grew.

MILLAR."

and to enclose, for your information and transmission to the relatives of the late Sister Freund, an extract from a letter dated 9th instant, just received from Cannes.

I also attach an extract from the minutes of a meeting of the Local Board at Cannes, held on the 4 th instant.

Will you please be good enough to convey to the relatives an expression of my Committee's deep sympathy with them in the irreparable loss which they have sustained.

I have asked Lieut. Colonel Casalis to furnish me with full details of Miss Freund's illness, of the steps taken to preserve and forward any personal effects, and of the procedure necessary to ensure the transmission of the Medaille des Epidemies to her relatives, and will advise you in due course on all these matters.

The following obituary notice was inserted in the "Times" at Lieut. Colonel Casalis' request:

"DEATH. - On May 4th at the South African Ambulance, Hospital Beau Rivage, Cannes, France, Sister Betty Freund, late of Luckhoff, O.F.S., South Africa, in her 31st year."

Yours faithfully,

\section{Hon Secretary}

Mr Councillor W.M. Martin, J.P., Hon. Secretary and Treasurer, South African Ambulance, 33 Adderley Street, Cape Town.

\section{THE REPORT}

South African Ambulance, Hospital Beau Rivage,

Cannes

7th May, 1918

SISTER ELIZABETH FREUND, late of Luckhoff, Orange Free State, South Africa, affectionately known to everyone alike as Betty, passed away at 2 a.m. on Saturday, 4th May, 1918, in her 31st year.

For some little time back she had not been in a very good state of health, but her valiant spirit refused to recognise defeat and she courageously stuck to her duty long after she ought to have given up. Ten weeks ago however, even her determination was forced to give way and she took to her bed. Everything that loving kindness, patient skill, and tried devotion could do was done, but her health took a sudden turn for the worse, and despite all efforts she passed away on the 4th.

As she had lived so she died, ever patient, ever self sacrificing thinking, of others before herself and suffering her vigil of pain with no complaint. It is indeed hard to express in adequate language the sense of personal loss, and bereavement, that all in the hospital have felt at this time. Sister Betty was such a lovable character, she was known throughout the hospital, by the humblest worker in the kitchen, by the poorest soldier and the highest officer, and by all the beauty of her character was felt.

Sister Betty was one of the few remaining members of the original staff, and save for a short period when she did duty on the first floor, has always been in charge of the third floor or Ward $E$ of the hospital. In her work she engendered in the minds of the soldiers a love and adoration which few of us can hope to do, her loving kindness, her skilful devotion and absolute self sacrifice to duty stand out as one of the ideals that all of us may aspire to but few hope to achieve.

Truly in her passing an influence has gone from the nursing staff which, infusing itself throughout their lives, made for all that was best and most true in one's conception of the ideal daughter of that noblest type of womanhood Florence Nightingale.

When the sad news became known in the hospital the spontaneous sorrow which was shown by 
the domestic staff, the soldiers in the wards even those who had known but little of her - the nursing staff and the medical personnel was a striking proof of the esteem in which her memory was held. A feeling which was exemplified by the profuseness of the floral tributes to her memory. One instance in passing might be given of the deep love for Sister Betty: A member of the kitchen staff, one who did his humble but necessary part for very little payment, had only three sous in his possession when the collection for the wreath was made, nevertheless he contributed all that he had, and grudged not the payment. Of such is our love for persons made.

The French Government has granted her the honour - which though received posthumously is none the less real - of bestowing upon her the gold Medaille des Epidemies for devotion to duty and services rendered to the great cause. So Betty Freund has gone, and we who knew her and love her for her manifest qualities can but mourn her, and keep bright in our memories the thought of what her life was, and endeavour to so mould ours that they follow on the same good plan. She has died in the glory of war for the right, as surely as any soldier who has fallen on the bloodstained field of honour in Flanders or France, and to her sorrowing father, mother, sisters and brothers we can only offer our humble sympathy in their loss, tempered by the feeling that at least she died an enviable death in the service of God and her country.

The first part of the burial service was held at 3.15 p.m. in the hall of the hospital, and the officiating minister, Canon Christie of Christchurch Church, Cannes, made feeling reference to her memory, speaking of the fact that she had come across continents to do her duty to mankind; this should be of some relief to her sorrowing relatives. He laid stress on the thought that death was not a parting for all time, but merely a gateway to another phase of life, which was larger and fuller of our earthly existence. Sister Freund's life held many things which it would be good for us to follow: her devotion to her duty, and sacrifice of self should encourage all who knew her to emulate her example.

Pastor Bonnefon, of the French Protestant Church, followed by addressing the people in French, and in a simple earnest speech, which touched all, he spoke of the noble thought of one who came so many thousand miles to minister to those who were strangers to her. He told the men what an inspiring thing it was to consider that, from all those many miles of land and water, she had come to work and labour for over three years among the battered heroes of France, and in the name of the French people he tendered their respectful sympathy and heartfelt condolences to the sorrowing relatives. The Medecin chef de la Place de Cannes then read out the message from the War Office bestowing the medal upon Sister Freund, and on behalf of the War Office of France tendered the thanks of the nation and their respectful sympathy to the relatives who were so far away.

On behalf of the soldier patients in the hospital, the officers on treatment, and all those who had passed through the skilful hands of Sister Freund since the inception of the Ambulance, Captain Aureggio, one of the patients, made a feeling address which touched the hearts of its hearers by the deep sense of tender feeling. We cannot do justice to the purity of the words, expressed as they were in the facile tongue of France, but we will endeavour as far as it is possible to render their sense into English without destroying their basic structure: - "In the name of all my comrades, and all those officers and soldiers who, since the beginning of the war, have succeeded one another as patients at the South African Ambulance, and have received the enlighted care of Sister Freund, I come to say thank you, and good-bye, to the one who was our devoted and experienced nurse. Devoted she was unquestionably, and how courageous! She has shown it well during these four years, in which time she gave profusely of her strength, to the extreme limit, in service to her wounded. How many times in the last few months, seeing her so tired, I, and many others - all those who loved her, and they are numerous here - have told her to rest a little and to spare herself. But she heard nothing save the voice of duty. Her malady she did not feel - she did not want to feel it. HOLD ON. She also wanted to 'hold on', to continue to look after her dear patients.

"But during the whole time her terrible inexorable malady was insidiously accomplishing its work. One day she gave up. I still see her that day gathering her last strength, gripping the bannisters of the staircase, to gain her room, which alas! she would never leave again save in her coffin. Indeed she had held on to the very last.

The skilful care of all those who until her last moments surrounded Sister Freund with their 
tender and affectionate solicitude, were to be powerless to retard the fatal end, but at least served in every possible way to replace the mother, to console her a little for the absence of her loved ones, detained over in distant Africa. Poor parents? I see them receiving the terrible news. Our daughter dead? Dead, Yes! but in the service of a noble cause. In their grief it will be their consolation and their pride. Kindly accept here the heartfelt expression of our deepest condolence.

"Sister Freund, rest in peace with the satisfaction of accomplished duty. You have been, in the South African Ambulance, a fine example of courage, bravery, and abnegation. We who have been tendered with so much devotion, bend down very low, and very respectfully, before your grave to tell you our grief and our gratefulness. Once more thank you, and GOOD BYE."

Sergt. Catelin, on behalf of the military and domestic personnel of the Ambulance, paid his tribute to the revered memory of Sister Freund. He told of the devotion to her work, of the love that all, both wounded and not, bore to her, and of the feeling of utter loss that was felt at her unti- mely decease. They, the workers in the kitchen, in the office and the wards, all felt more than they could express in words the deep loss that had been sustained, and a message of thanks would go out to South Africa from the French people's hearts for the good that had been done by the service of Sister Freund.

Colonel Casalis, who spoke with deep emotion, told in impressive words of the service of Sister Freund to the unit from the time when it left the shores of South Africa to the time of her death. He knew how dear to the hearts of all present she was, how to soldier, or nurse, to officer or sister alike she was ever the same, ever ready at the call of duty. Few words were needed from him as Chief of the Ambulance to show how much Sister Betty was loved by all who came in contact with her. The words of Captain Aureggio and Sergt. Catelin showed in what esteem she was held both by the patients and the personnel. He would say on behalf of the South African Ambulance that all the members of that body tendered to the family in their great bereavement their deep sympathy in the irreparable loss which they had sustained. Sister Freund had indeed died, but she had died doing her duty in the Great Cause.

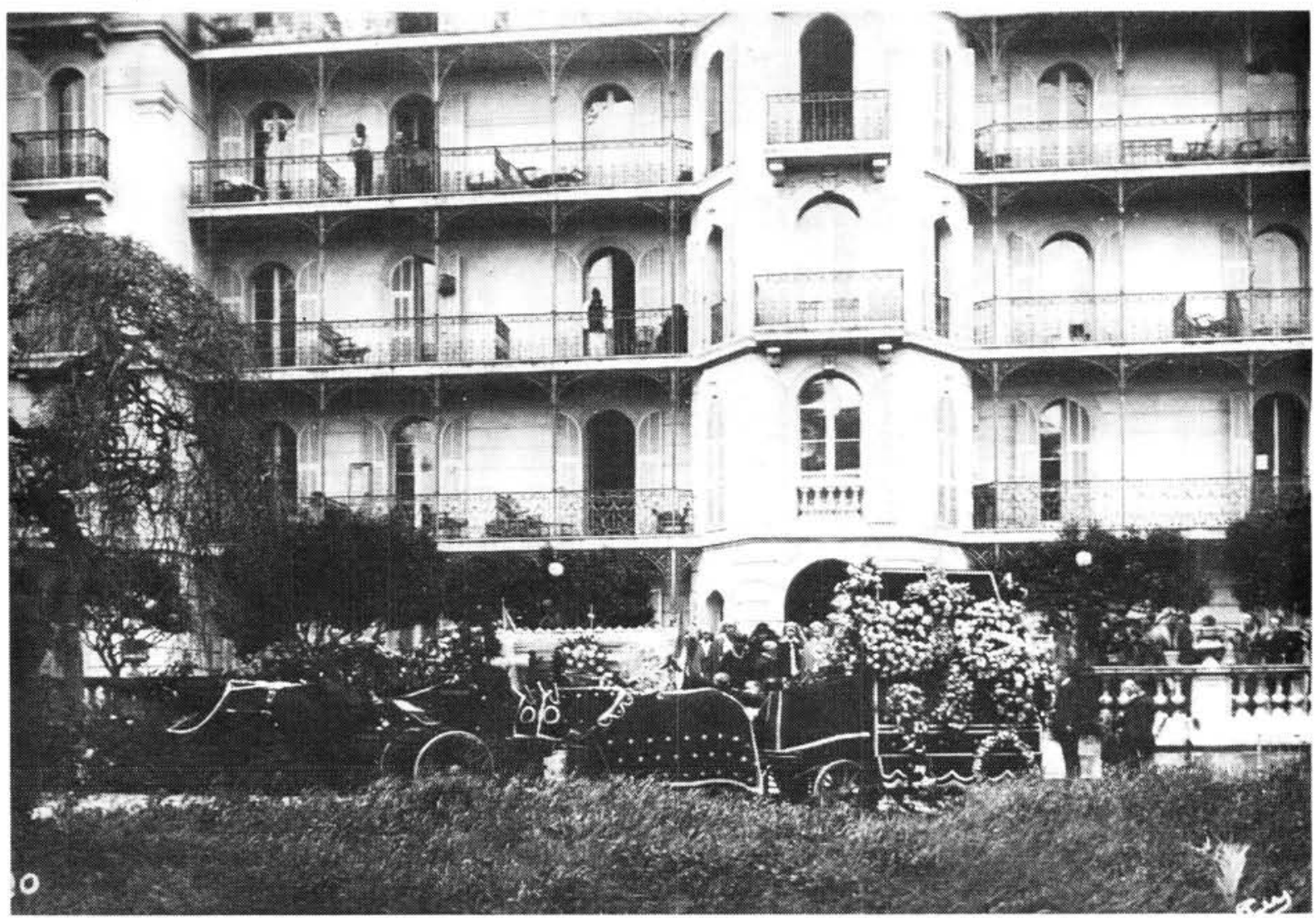

Front view of Beau Rivage Hospital (the hotel converted into a hospital during the Great War) on the day of Betty's funeral 
At 4 p.m. the cortege left the hospital, for the cemetery on the hill, where the mortal remains of Sister Freund would be laid to rest overlooking the scene of her labours of love.

Preceding the hearse, which was draped with the Allied Colours, the Union Jack and the Flag of the South African Ambulance, was a carriage containing the numerous floral tributes to her memory. On each side of the hearse were the nurses of the Ambulance headed by Sister Archer Isaac and followed by Dressers C.L. Darley-Hartley and F. Claes, the only members of the original staff left, and immediately behind the coffin were Lt. Colonel and Madame Casalis, representing the family; following them were $\mathrm{Dr}$. Baily and Mrs. Topham, the Medecin Principal of Cannes, Dr. Bufnoir, Medecin Chef Hospital Gallia, Mr. Vaucher, the administrator of the Ambulance, Mr. Hainzl, representing the Municipality, Major Tournaillon, Drs. Wegelin, Laurent and Zuber, nurses of the Association des Dames de France and Canadian nurses, the officer patients and all the soldiers in the hospital who could walk, with many members of the domestic staff. The two motor ambulances also carried many men who were unable to walk the distance but still desired to pay their last respects to Sister Freund. The procession, which stretched along the broad Croisette, was one of the most imposing that Cannes had seen.

The interment took place in the Protestant portion of the cemetery and was conducted by the Revd. Cannon Christie.

Among the numerous and varied floral tributes were:

The Freund Family. "To their beloved daughter and sister."

Colonel and Mrs. Casalis. "To dear Sister Betty from Colonel and Madame Casalis."

S.A.A. and London Committee. "To Sister Freund. S.A.A. Faithful unto death."

Medecin Chef and the Service de Santé. "De la Part du Médecin Chef de la Place et du Service de Santé,"

Commandant and Madame Tournaillon. "With deep sorrow. 1914-1918."

Sister Archer Isaac. "To Betty. In loving memory. Archer."

Nursing Staff. "A Sister Freund T'emoingnage d'affection et de regrete de toutes ses compagnes de l'Ambulance Sud Africaine."
Medical Staff: Officer Patients. "A Sister Freund. Les Officiers de l'Ambulance Sud Africaine."

Soldier Patients. "Les Blessés de l'Ambulance Sud Africaine en Reconnaisance. A leur dévouée infirmiére Sister Freund."

C.L. Darley Hartley. "Pax Eterna."

Fr. Claes. "Rust in Vrede."

Philip A. Papineau.

Mr. and Mrs. Topham.

Miss Topham.

Dr. Edwin baily.

Mrs. Henry Brock.

Miss Campbell.

Revd. and Mrs. Clement Brown.

Employées. "A Sister Freund le personnel civil de l'Ambulance Sud Africaine."

Souvenir Francais. Sent to every French Soldier dying for France.

Miss Paget. Bouquet of flowers from her own garden.

Madame R. Aureggio, wife of one of the Officer Patients.)

R. and H. Folkett. "In loving memory."

Mrs. Wenz. "In loving memory from Anna."

Misses M.A. and B. Smellie. "In loving memory."

Miss Roy.

Mr. and Mrs. Blanchi. "Avec tout affection."

Miss Florence Sharpe.

Miss Jones.

Mrs. H.R. Phipps.

Mademoiselle A. Seillier.

Mrs. Papineau.

Madame A. Parlarghij.

Madame Justine Maton.

Madame Marie Louise Richards and daughter.

\section{SPECIAL MEETING OF THE A.S.A.}

A Special Meeting of the Board was held on May 4th. All the members were present. Colonel $\mathrm{Ca}$ salis presided.

Dr Baily rising, spoke of the great cloud which overshadowed the Ambulance. They had been summoned as a Board to give verbal expression - if it were possible - to the poignancy of the grief which they one and all felt that day in the death of Sister Elizabeth Freund. A great sorrow felt indeed by every member of the Ambulance, but to Colonel and Madame Casalis and Sister Archer came not only the loss of a devoted colleague, but the severance of an old personal friendship, a friendship of days before the war. 
Sister Freund was amongst the earliest of the volunteers to offer her services to France. Forgetful of home and her native country she responded to the call of duty. From the inception of the Ambulance she had been one of its most devoted workers. Heedless of self, mindful only of France's wounded and sick soldiers, she had spent her life and her strength for them. During the last four years she had indeed given of herself freely, and she had fallen in the midst of her most active duties. With rapidly failing strength Sister Freund had not relinquished her post until she fell a victim to the fatal malady which she had contracted while on service. In those years of service she had made her own memorial, and there was left now her example of devotion, duty and courage, which must ever remain on record in the history of the Ambulance.

Dr Baily moved that an excerpt of this minute be forwarded to Mrs Freund and that the meeting do thereafter adjourn.

Colonel Casalis rose in support of the motion. In a few words he expressed his inability at such a moment to add anything to what had already been said - no words could adequately express his sense of loss. Speaking personally for himself and for those who had been most closely associated with him since the day the Ambulance Sud Africaine sailed from South Africa, he and they could only think of the loss which had so suddenly come upon them, and of the irreparable blank which had been created in the Ambulance.

The motion was then unanimously agreed to by a silent motion of assent.

The Acting Secretary having been instructed to forward an intimation of the death of Sister Freund to the "London Times" and the Continental "Daily Mail" (Paris), the meeting did thereafter adjourn.

Ambulance Sud-Africaine

Hôpital Beau-Rivage $N^{\circ} 156^{\text {bis }}$

Cannes

14th September 1918

\section{My Dear Mrs Freund,}

Madame Casalis is away at the present time and I am therefore writing to you about your dear daughter's grave.
The work has now been completed, and I am enclosing six photographs of the grave together with six of the surrounding portion of the cemetery. You will see from these how your wishes for the perpetuation of Betty's memory have been carried out. The grave looks lovely now with the sweet little shrubs growing round it, and the beautiful cross at its head. I am sure you will feel that we have done all we could do to carry out your desires, not only for yourself and your family but also because of our love for your noble daughter who was so dear to all of us. There never can be anyone else like Betty in the Ambulance, even now every day one misses her presence, and looks for her. Something has gone from the hospital which can never be replaced, but the memory of that presence will always be fresh in our minds, the minds of all those who knew and loved dear Betty. Oftentimes the servants speak to me of "le pauvre Sistre", and the men in the wards sorrowfully shake their heads. In your sorrow dear Mrs Freund it must be some relief, almost a joy, to think that your daughter was so beloved by all who knew her that her memory remains such a tangible thing even now that some months have passed. There is hardly a member of the nursing staff who has not at some time or another been in Betty's hands as a patient and who has known the loving kindness with which she ministered to them. Very often our thoughts go towards the little spot in God's Acre where she is now resting in her last sleep, and today, being the anniversary of her birthday, all who could went to lay some small tributes of flowers on her grave, Sister Archer Isaac, Misses Topham, McKean and Campbell and myself, and also Mrs Topham. The ground is being kept beautifully and everything is being looked after so well.

I want to thank you very much for the letter which you sent to us all, I feel very much the gratitude you have expressed for the little we have been able to do to take your place but we did it all because of our love for Betty.

With very deepest sympathy to you all,

Believe me, dear Mrs Freund,

Yours sincerely,

\section{B.L. Darley-Hartley}

Mr C.L. Darley-Hartley became the Business Manager of the South African Medical Association at the time when Dr C. Louis Leipoldt was Secretary of the Association and Editor of the S.A. Medical Journal. His father was Dr W. Darley-Hartley, who founded the S.A. Medical Record. Mr Darley-Hartley was a 'dresser' at Beau Rivage at the time when Betty Freund was there. He died in December 1958. 


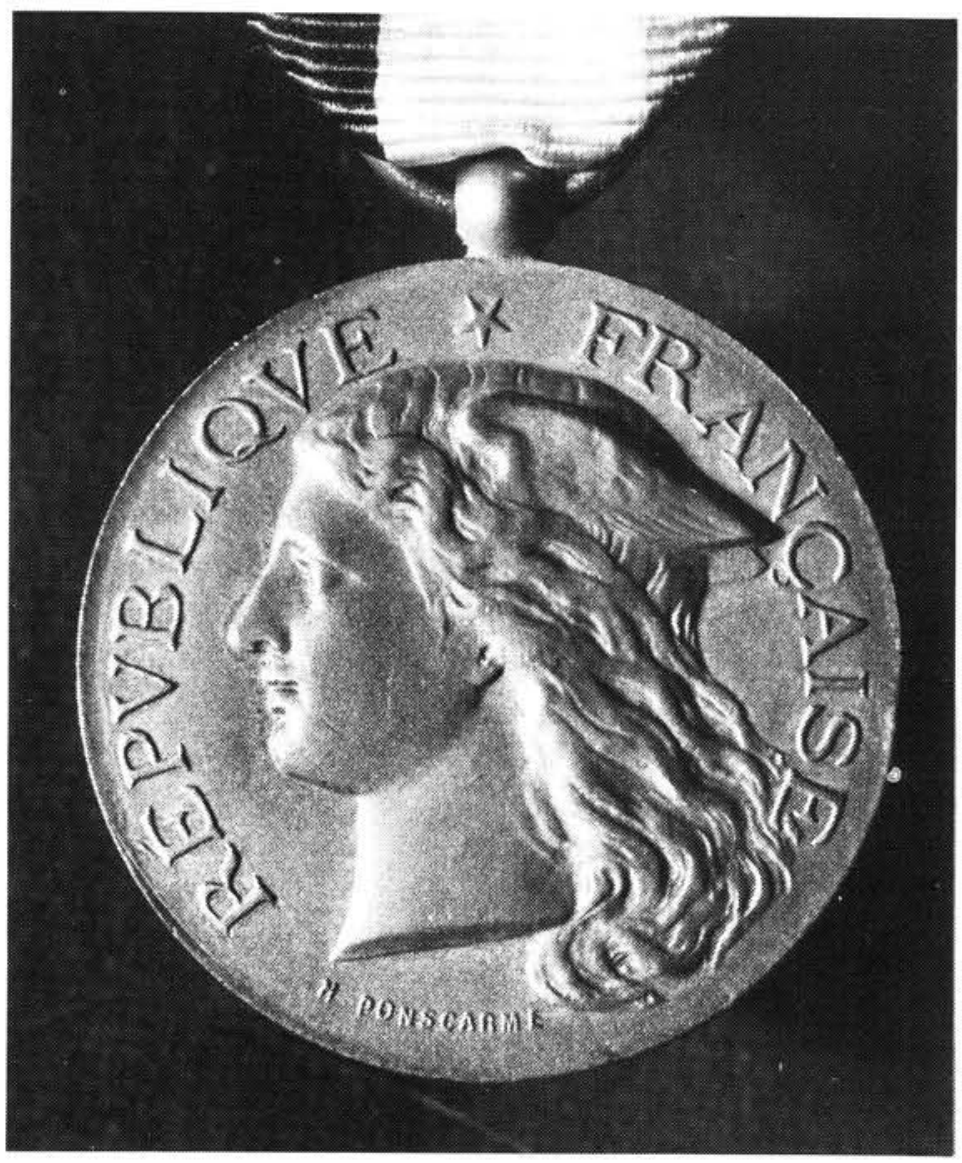

The Médaille d'or des Epidémies awarded to Betty Freund by the French Government (enlarged)

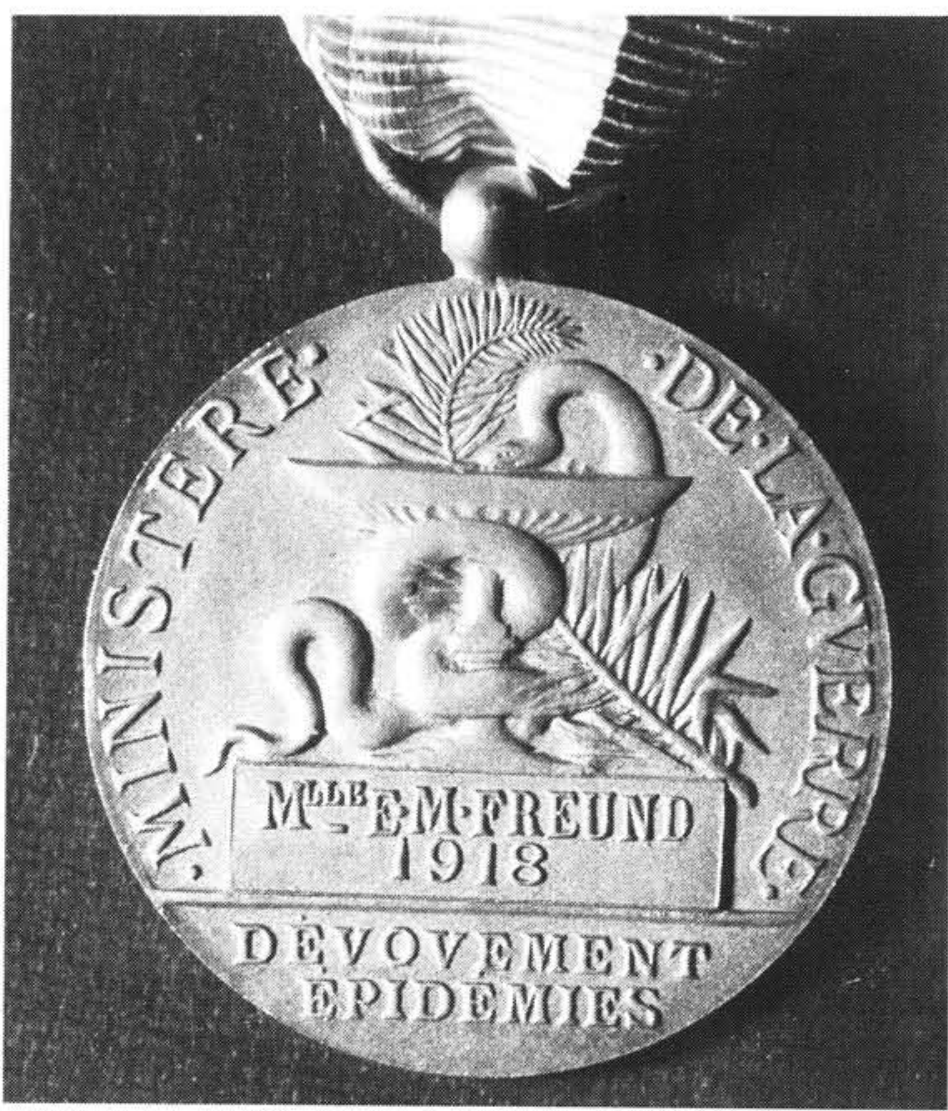

The reverse side of the Medal, with the inscription 


\section{FRENCH TRIBUTE TO S.A. NURSE}

\section{Sister Betty Freund}

"... The memory of the just Smells sweet and blossoms in the dust."

The news of the death of Sister Betty Freund - to give her the less formal name by which she was known and beloved - came as a great blow to all who knew her here, in her native land, and the following extracts from documents from France are published in the knowledge that many will be glad to know something of the work done by this daughter of South Africa for our sick and wounded French Allies, and the esteem in which she was held by them.

Sister Freund, late of Luckhoff, Orange Free State, was an elder sister of Miss Mina Freund, so well-known to us all as a talented elocutionist and Shakespearean actress. She was nursing in Johannesburg when the war broke out, and was one of the first to volunteer for service in France with the South African Ambulance, which proceeded overseas under Dr Casalis, in 1914, and was established at the Beau Rivage Hospital, Cannes. For nearly four years Sister Betty was one of its most devoted workers. Spending her life and her strength for the suffering soldiers of France, she passed away in the midst of her duties. In the words of those most closely associated with her. "With rapidly failing strength Sister Freund did not relinquish her post until she fell a victim to the fatal malady which she had contracted on service. In those years of service she made her own memorial and left an example of courage and devotion to duty which must ever remain on record in the history of the Ambulance."

She died on the 4th May, 1918, after having been laid up for ten weeks, "ever patient, ever self-sacrificing, thinking of others before herself, and suffering her vigil of pain without complaint." The French Government conferred on her the Gold Medaille des Epidemies for devotion to duty and services rendered to France, and she was accorded a military funeral in the cemetery on the hill overlooking the Hospital. The funeral procession was one of the most imposing ever seen in Cannes. The hearse, draped with the Union Jack, the flag of the S.A. Ambulance and the colours of the Allies, was preceded by a carriage filled with the beautiful wreaths and flowers sent by friends, officials and committees. On each side were the nurses of the Ambulance, headed by Sister Archer Isac and followed by Dressers Darley-Hartley and Class, the only members of the original staff left, and immediately behind the coffin were Colonel and Madame Casalis as chief mourners, representing the family, with Dr Baily and Mrs Topham, the Medicine Principal of Cannes, Mr Vaucher, the Administrator of the Ambulance, Mr Hainzl, representing the Municipality, Major Tournaillon, Drs Wegelin, Laurent and Zuber, nurse of the Association des Dames de France and Canadian nurses, the officer patients and members of, the domestic staff. Two motor ambulances carried many men who were unable to walk the distance, yet who wished to pay this last tribute to one they loved. The service was conducted by Canon Chrisie, of Christ Church, Cannes, who, speaking in the hall of the Hospital, where the first part of the service was held, made touching references to Sister Freund's sorrowing relatives, her devotion to duty and sacrifice of self.

Pastor Bonnefon, of the French Protestant Church, spoke simply and earnestly of her labour of love for over three years among the battered heroes of France, and the Chief Medical Officer of Cannes read the message from the French War Office bestowing the medal on Sister Freund, and on behalf of the War Office of France tendered the thanks and respectful sympathy of the nation to the relatives who were so far away.

One of the most touching addresses was by Capt. Aureggio, a patient, on behalf of his comrades, both officers and men, in which he told of the benefits they had received by being tended by so devoted and experienced a nurse, who had given lavishly of her strength in service to her wounded, unheeding of the repeated entreaties of those who loved her to rest a little and spare herself. But, hearing nothing but the voice of duty, she had held on till the very last, and all the skill and tenderness in the world had been powerless to save her. "Sister Freund," he concluded, "rest in peace, with the satisfaction of duty well done. You have been in South African Ambulance, a fine example of courage, fortitude and abnegation. We who have been tended with so much devotion, bend down very low and very reverently before your grave to tell you of our grief and our gratitude. Once more, thank you, and good-bye."

Even the workers in the kitchen, in the offices 
and the wards expressed (through Sergt. Catelin) their sense of the deep loss they had sustained, and sent a message of thanks to South Africa from the hearts of the French people for the services rendered them by Sister Freund.

To Colonel and Mrs Casalis Sister Betty's death means the loss of a personal friend, as well as of a devoted colleague, for their friendship dates to pre-war days. "It is indeed hard to express in adequate language," says Colonel Casalis, "the sense of personal loss and bereavement that all in the Hospital have felt at this time. Sister Betty was such a loveable character; she was known throughout the Hospital, by the humblest worker in the kitchen, by the poorest soldier and the highest officer, and the beauty of her character was felt by all. In her work she engendered in the minds of the soldiers a love and adoration to which few of us can hope to attain. Her loving kindness, her skilful devotion and ...... the nursing staff which, infusing itself throughout their lives, made for all that was best and truest in our conception of an ideal daughter of that noblest type of womanhood, Florence Nightingale. When the sad news became known in the Hospital, the spontaneous sorrow which was shown by the domestic staff, the soldiers in the wards - even those who had known but little of her - the nursing staff and the medical personnel was a striking proof of the esteem in which her memory was held ... So Betty Freund has gone, and we who knew her and loved her for her manifest qualities can but mourn her, and keep bright in our memories the thought of her life, and endeavour so to mould ours that they may be modelled on the same good plan. She has died in the glory of War-for-the-Right as surely as any soldier who has fallen on the bloodstained field of honour in Flanders or France, and to her sorrowing mother, sister and brothers we can only offer our humble sympathy in their loss, tempered by the feeling that at least she died an enviable death in the service of God and her country."

•Extract from: The Cape Times, May 1918

\section{AMBULANCE}

\section{The Late Sister Freund From a Correspondent}

Sister Elizabeth Freund, late of Luckhoff, Orange Free State, South Africa, affectionately known to everyone alike as Betty, passed away a 2 a.m. on Saturday, May 4, 1918, in her 31st year. For some little time back she had not been in very good state of health, but her valiant spirit refused to recognise defeat and she courageously stuck to her duty long after she ought to have given up. Ten weeks ago, however, even her determination was forced to give way and she took to her bed. Everything that loving kindness, patient skill, and tried devotion could do was done; but her health took a sudden turn for the worse, and despite all efforts she passed away on the 4th. As she had lived, so she died, ever patient, ever self-sacrificing, thinking of others before herself and suffering her vigil of pain with no complaint. It is indeed hard to express in adequate language the sense of personal loss and bereavement that all in the hospital have felt at this time. Sister Betty was such a lovable character, she was known throughout the hospital, by the humblest worker in the kitchen, by the poorest soldier and the highest officer, and by all, the beauty of her character was felt. Sister Betty was one of the few remaining members of the original staff, and save for a short period when she did duty on the first floor, has always been in charge of the 3rd floor or Ward E of the hospital. In her work she engendered in the minds of the soldiers a love, and adoration which few of us can hope to do, her loving kindness, her skilful devotion and absolute self-sacrifice to duty, stand out as one of the ideals that all of us may aspire to, but few hope to achieve. Truly, in her passing, an influence has gone from the nursing staff, which infusing itself throughout their lives, made for all that was best and most true in one's conception of the ideal daughter of that noblest type of womanhood, Florence Nightingale. The French Government has granted her the honour of bestowing upon her the Gold Medaile des Epidemies for devotion to duty, and services rendered to the great cause.

The first part of the burial service was held at 3.15 p.m. in the hall of the hospital, and the officiating minister, Canon Christie, of Christchurch Church, Cannes, made feeling reference to her memory, speaking of the fact that she had come across continents to do her duty to mankind; this should be of some relief to her sorrowing relatives. He laid stress on the thought that death was not a parting for all time, but merely the gateway to another phase of life, which was larger and fuller than our earthly existence.

On behalf of the soldier patients in the hospital, the officers on treatment, and all those who 
passed through the skilful hands of Sister Freund since the inception of the Ambulance, Capt. Aureggio, one of the patients, made a feeling address which concluded as follows: "Sister Freund, rest in peace with a satisfaction of accomplished duty. You have been, in the South African Ambulance, a fine example of courage, bravery and abnegation. We who have been tended with so much devotion, bend down very low, and very respectfully, before your grave to tell you our grief and our gratefulness." At 4 p.m. the cortege left the hospital for the cemetery on the hill, where the mortal remains of Sister Freund would be laid to rest overlooking the scene of her labours of love. Preceding the hearse, which was draped with the Allied colours, the Union Jack and the flag of the South African Ambulance, was a carriage containing the numerous floral tributes to her memory. On each side of the hearse were the nurses of the Ambulance, headed by Sister Archer Isaac and followed by Dressers C.L. Darley-Hartley and F. Class, the only members of the original staff left, and immediately behind the ....... were Col. and Madame Casalis representing the family, following them was Dr Baily and Mrs Topham, the ....... Principal of Cannes; Mr ....... the Administrator of the Ambulance, Mr Hainzl, representing the Municipality, Major Tournaillon, ....... Wegelin, Laurent and Zuber, nurses of the Association des Dames de France, and Canadian nurses, the officer patients and members of the domestic staff.

*Extract from: The Cape Times, May 1918

\section{S.A. AMBULANCE IN FRANCE}

At the last meeting of the Cape Town Executive Committee reports dealing with the following matters of interest to those who have assisted in maintaining the South African Ambulance at Hospital Beau Rivage, Cannes, were submitted:

The daily average number of patients treated at Beau Rivage in February was 186, and in March 97; and at Villa Felicie 29 in February and 27 in March.

The amount of surgical work done at Beau Rivage exceeds that at any other of the hospitals in Cannes. The reputation of Beau Rivage is still maintained and special surgical cases are being sent there with increasing frequency.
Amongst the recent inmates were the Chief of the Military Mission of the United States Army to the French Army; an English soldier, with a very severe fracture of the femur; a nephew of Dr Casalis, who had come from the Greek front; and several men from the French China possessions, from West Africa, and from Martinique.

An Italian soldier arrived at Beau Rivage with his arm badly poisoned. Despite the attention given to him he died, after many days of suffering. His coffin was draped in the Italian flag.

The medical officers of the S.A. Ambulance attend the British Army Nurses at the "Esteral" Rest Home, where there are at times about 100, and also the Home for Refugees from the invaded departments of France. The latter are for the most part aged couples.

Mr C.L. Darley-Hartley, of Cape Town, has rejoined the staff at Beau Rivage after being discharged from the London Regiment on account of wounds.

Cable advice was received early this month notifying that Sister Freund died on May 4, and that particulars are coming by mail. The sympathy of the members of the London and Cape Town Committees has been conveyed to her sister, Miss Mina Freund. From a later cable it is learned that the French Government have awarded Sister Freund the Gold Medaille Des Epidemies in recognition of services rendered.

Several dramatic entertainments and concerts have been given by the staff at Cannes and, while these have helped to lighten the hearts of the patients and others, the proceeds have been devoted to various War Funds - the S.A. Ambulance participating. Donations in money and kind continue to be received at the hopsital.

A comparison of the cost of food, etc., as between the last quarters of 1916 and 1917 shows an aggregate increase of 55 per cent, and it has only been by the most painstaking attention on the part of the local management at Cannes to all details of expenditure that the cost of maintenance has worked out at only 4 francs per day per person.

A slight but very welcome increase took place in the amount of contributions received at Cape Town during the month of April. The receipts from January to April, 1918, averaged £190 per month. The disbursements were slightly under 
$£ 300$ per month during the same period. Funds are urgently wanted to enable the committee to maintain the monthly remittances to France.

The feeling expressed by the members of the committee was one of confidence that the wherewithal to keep the S.A. Ambulance going would be forthcoming if its need were made known widely, and they decided that a very urgent appeal for special contributions should be made to the public, as well as to those who have more or less regularly and consistently contributed towards the maintenance of the unit since it was raised and despatched to France in 1914; also that their cordial thanks for all past assistance and support be publicly recorded.

Donations should be forwarded to the hon. secretary and treasurer, W.M. Martin, J.P. Box 16; or Guardian Buildings, 33 Adderley Street, Cape Town.

*Extract from: The Cape Times, 21 May 1918

\section{A LUCKHOFF HEROINE}

\section{French honour to late nurse Freund From our own correspondent}

Lieut.-Colonel G. Brand visited Luckhoff on December 4th, having been asked by the Minister of Defence personally to present to Mrs J. Freund the Distinguished Gold Medal awarded by the French Government to her late daughter, Sister Betty Freund, who passed away in France in May last. Shortly after the outbreak of the war, the late Miss Betty Freund proceeded to France, where she was actively engaged in a French hospital in assisting and attending to the sick and wounded until her death.

The presentation was made at 11 o'clock in the Court House, where the whole Freund family and a large number of friends assembled.

Lieut.-Colonel Brand, in a short and appropriate speech in English, and afterwards repeated in Dutch, made known his mission to Luckhoff, and said that the gold medal which he was about to present to Mrs. Freund was a rare honour awarded by the French Government only to the most distinguished of the nursing staff who did excellent and untiring service in alleviating the pains and miseries of the sick and wounded from the front.
Rev. van Wyk, in a short speech in Dutch, on behalf of Mrs. Freund and family suitably thanked Lieut.-Colonel Brand for coming over to Luckhoff to make the presentation personally. He said that they could all feel proud that Luckhoff has produced a lady of such sterling quality and the honour bestowed on Mrs Freund's late daughter would to some extent compensate for the sad loss to the whole family in her demise. He said, further, that, although the presentation and speech was very well made by Lieut.-Colonel Brand, it could, however, be noticed that he would have felt more at home and in his place if he had the command of a regiment in the field in the battle line than making speeches and performing such duties as fell to his lot that day.

*Extract from: The Friend, December 1918

In June 1925 a Memorial Service was held at the Cape Town Cathedral as a tribute to the 'Sisters of the Empire' who had laid down their lives in the Great War.

The famous "Five Sisters" Window in York Minister has been restored in memory of "The Sisters of the Empire" who gave their lives in the Great War; and their names are inscribed on an Oak Screen adjacent to the window.

The Sisters of South Africa who gave their lives:

Constance Addison
Edith Agnes Baker
Kaloolah Beaufort
Dora Bernstein
Eleanor Eileen Black
Dorothea Kathleen Bolus
Gertrude Eliza Dunn
E. Edgar
Constance Alexandria Edmeades
Marguerite Muriel Erskine
Daisy Alotta Fitzhenry
Elizabeth Freun
Beatrice Hearns
Olive Hockey
Mina Macdonald
Annie Winifred Munro
Pauline Hermione Emily Paff
Ida Wardle
Julia Kathleen Watkins

Elizabeth Freun (the ' $d$ ' at the end left out) was, as I have said, one of many and her 'story' would have been forgotten if the family had not 
kept all the papers, documents, letters, photographs, the medal itself, and dozens of other odds and ends such as an apron, the trunks in which her things were sent back, and so on.

\section{The following is an excerpt from a letter of my cousin, May Roux, who was present at the ceremony in Luckhoff when Lieut.-Colo- nel Brand (who was a son of the old Presi- dent Brand of the Orange Free State) handed over the medal to John and Metha Freund:}

'... a cable came to say "come at once", and I think it must have had something to the effect "Betty dying", but the "come at once" I remember very well. Arrangements were made to send uncle Willy over - in those days such an arrangement would have taken quite a few days to complete - but before a passage could be booked for Willy, another cable arrived to say that Betty had passed away. Then came the long wait for further news while Betty's weekly letters kept arriving. Each letter brought such heartache, such bitter tears from Ouma - this made a great impression on me. Old John Freund (Oupa) seemed quieter, bearing his grief in silence. When the trunks arrived - first one, and some time later another - Ouma would open them and then wait for my mother to come over at weekends to help her to unpack them. All Betty's things had been beautifully packed ....

The Freunds were invited to go to Pretoria for the presentation of Betty's medal at an official occasion, but Ouma refused to go. This is why the ceremony was then held at Luckhoff ... Lieut.-Col. Brand had a son Johnny who went to Grey College at about the same time I was at Greenhill Convent there ... and this son became a doctor in the Free State somewhere ....

I can remember walking to the Court House in Luckhoff on the day of the presentation, my mother telling me to keep my white shoes out of the sand ... Ouma and Oupa arrived in a car driven by uncle Freddy, I think, and Ouma sat on a chair in the aisle between the rows of seats, the family sitting in the front rows. After the presentation the public was given a chance to speak and I remember one speech in particular, made by a Mr At Lampbrecht, in which he said that if anyone had earned a place in Heaven, Betty's deeds had surely secured a place for her there.

\section{BETTY FREUND'S LETTERS TO HER MOTHER}

\section{Editorial note:}

I have altered nothing in the letters except occasional spelling errors, and punctuation for the sake of clarity. Where the text has dots it means that I have left out irrelevant details - such as family affairs, descriptions of flowers and scenery, references to holiday trips, teas, and other trivial matters. I have also left out Betty's occasional criticisms of people and references to internal problems encountered by the Ambulance. After all these years there seems to me no point in dwelling on such matters when it is the lasting achievement - the good that was done - that is worth remembering.

\section{Letter from Hofmeyr Street, Cape Town}

19 November 1914

\section{Dear Mama,}

... On Tuesday we were kept busy all day, we had to get our uniforms and everything ready we all met at Dr's rooms, they are near Cartwright's. Our motor ambulances fetched us there and drove us out to Government House, Newlands. You should have seen the crowd about us when we started, they cheered and cheered us. At Government House the Ladies of the Committee received us and never in my life have I seen so many cameras, you could not move or look up or somebody was snapping you. Two Bioscope comp. took films too, they are sending some of the films to London as well, all the Newspaper men were there and the Ladies Pictorial as well. Lady Juta was most charming to me, she came up to me and said, "you must be Mina's sister" ...

Gen. Thompson came to inspect us, he is such a nice old man, and shook hands with all of us. His son was killed in France only a month ago. The old Arch-Bishop was awfully nice and ... wishes us God-speed.

We were given tea under the beautiful old oak trees with our flag flying amongst us. They motored us back to Town at 6 o'clock and we got presented with most beautiful flowers and I wished I could have sent them to you ...

A French girl from Johannesburg is going with us and one from Salisbury ... heaps of girls in the Hospital Johannesburg say how they would have loved to have gone and they were all so excited when they heard I was going ... 
We are sailing on Saturday at one o'clock. I'll write a short note before we leave although you'll get it same time s this -

Love to you all from

Betty

Lady Juta was Helen Lena Tait, wife of Henricus Hubertus Juta, who changed his name to Henry Hubert. He was the second son of J.C. Juta who founded the publishing house. Sir Henry went to school at S.A.C.S. and took his LL.B. in London where he was admitted to the Bar at Inner Temple. He came back to the Cape in 1893 and was M.P. for Oudtshoorn and Attorney-General for the Rhodes Ministry. In the first Union Parliament he represented the Harbour Division of Cape Town. Sir Henry and Lady Juta had one son and four daughters. One of the daughters, Rene, married Sir Luke Hansard. Rene was in France during the Great War; she also nursed in Cannes. She subsequently wrote a novel The Tavern, based on the story of James Barrie, and Cannes and the Hills in 1924, and Concerning Corsica in 1926.

Sir Henry Juta, on his mother's side, was a nephew of Dr Karl Marx, the father of Communism. Marx's sister Louise married Jan Carel Juta, a Hollander, in 1853 and it was Jan Carel - Sir Henry's father - who later established the well-known South African Publishing House.

General Thompson: This was Charles William Thompson, (C.B.) (D.S.O.) born 24 November 1859. After a distinguished military career - he had served, inter alia, during the Egyptian Campaign in 1882, and during the Anglo-Boer War of 1899-1902 - he was appointed Officer Commanding of the Cape of Good Hope on 21 June 1913. In September 1914 he became temporary Major-General and Chief of the Imperial Staff in South Africa.

'The old Archbishop' referred to here was William Marlborough Carter, KCMG DD, who was Bishop of Cape Town from 1909 till 1931.

\section{Aboard Union-Castle Line RMS Saxon}

29 November 1914

My dear Mama,

It is more than a week since we left the shores of Africa and everything seems so far away, you hardly realise that this awful war is still going on. I often wonder how things are in the Free State and how you are all getting on and I am fearfully worried about you all at times...

So far we have had glorious weather, yesterday and to-day it is rather hot, but on Tuesday we hope it will be much cooler and, of course, after that it will be awfully cold. I am looking forward to the snow and am so pleased to be able to go to Europe, if it were only under different circumstances ...

We travel in perfect darkness, you are not allowed to have your porthole open if there is a light in your cabin, and no lights on the decks at all ...

We have roll call at 10 every morning and then different lectures till 12 o'clock and after that a
French lesson. Matron was awfully ill the first few days but is better now, she is so nice and charming to all of us and I really like her. Dr Casalis is as nice as ever...

We are not landing at London but at Plymouth ... they consider it safer. We have no idea how long we will be in London at all, but I'll write to you from there. Please dont forget to write every week and tell me how you are.

Much love from your loving daughter

Betty Freund

\section{S.A. Ambulance, c/o High Commissioner for S.A., 32 Victoria St., London S.W.}

17 November 1914

My dear Mama

The South African mail is not yet in but l'll start my letter to you as we might be going over to France any day now and the mail closes to-morrow...

I could not continue my letter yesterday as some visitors came to tea ... Maj. Casalis had a letter from the French "Minister of War" and he said we were attached to one of their five Regiments, but did not say where, we may have to spend Xmas in London after all. They seem so slow in France ...

You don't feel or hear much about the war - only yesterday there was some excitement when it became known that the coast had been shelled. How are you all at home? I hope the Rebellion is over by now and that everything is the same again. Don't go out to the farm so much. Have you had those injections and have they done you any good? Write every week,

Your loving daughter

Betty

The reference to 'some excitement' here concerns the bombardment by German cruisers of Hartlepool, Scarborough, and Whitby on 16 December. This caused great consternation, in fact, as 500 civilians were killed or wounded (Gilbert: First World War Atlas, p. 75).

The Rebellion was led by a group of Afrikaners in the Transvaal and the Free State who were opposed to the invasion of S.W.A. They saw an opportunity to regain their independence while Britain was at a disadvantage.

As a matter of fact, the Rebellion was extensively reported in The Times, among other papers, but Betty may not have had access to papers or may have missed these reports. 


\section{From London}

\section{December 1914}

My dear Mama,

Last week when the mail came I was fearfully disappointed to find that there was no letter from you after all, but Mina wrote and several other people. During the week I got a letter from you forwarded on to me which you had written to me to the boat in Cape Town ...

We are going over to France next week, New Year's day most likely. We are going down to the South of France to the Riviera, to Cannes. They are fitting up one of the lovely big Hotels there for us, that is why we had to wait here so long ... we will be in all comfort in one of the most beautiful places of this earth and it will be warm there. I am dreadfully sorry we are not going right to the front. I would have liked to have gone but we might get there yet. Some more Drs from Edinburgh are going with us. Lady Juta's one daughter, Miss Schreiner (the High Commissioner's daughter), and other South African Ladies who are in London, all such nice girls -

Everywhere you see Xmas trees and it is lovely being out amongst the people all doing their Xmas shopping, boys and girls come round in the evenings and sing Xmas carols, it does sound so pretty. There is of course a lot of sadness and sorrow this Xmas. Heaps of people in black, but nowhere do you see people excited or standing by the hour talking about the war. London in darkness is not so bad as it is made out either, neither are the people living at a high nervous strain as they said in the Cape Times...

You can't help admiring the English taking everything very calmly. Of course, heaps of men have gone to the war, and everywhere they are working overtime. The post is only delivered 4 times a day instead of 6 , the milk man only comes round twice a day instead of three times, as his assistant has gone to the war. There is hardly a house where someone has not gone. Heaps of the officers over in France and some of the men who went over at the start of the war have got 10 days leave. They come and go over in batches. And do you remember the buses? Well, half of the London buses are in France taking the soldiers as they land to the front. The war has reached such a stage now that it is more like a siege - the trenches opposite each other, some places they are so near that the English and German soldiers speak to each other.
I hope you are well. Write every week. Love to all of you. Yours with love.

\section{Betty Freund}

'Miss Schreiner': this was probably Dorothy, the elder daughter of Frances Hester Reitz (sister of Francis William Reitz, President of the Orange Free State) and William Philip Schreiner, Prime Minister of the Cape Colony from 1891-1900 and brother of Olive Schreiner. William Philip Schreiner was High Commissioner in London from 1914-1918; he died in 1919. Dorothy and her sister Ursula both nursed at Beau Rivage while Betty was there.

There are photographs of these buses, in 'war paint' while they were in Flanders. There is one, for example, in the Great War Museum in Lambeth.

The comment on trench warfare is interesting: it shows that some details of the fighting had already reached the civilian population.

\section{From London}

31 December 1914

My dear Mama,

I heard this morning that the South African mail would not be in till Monday, as it is coming in an intermediate boat, wo we'll have no letters this week at all .... .

Mary's cousin is dangerously wounded. He was wounded in 19 places, and it was 44 hours before he was attended to, lying on the battlefield whilst the battle was going on, with hundreds of other wounded ....

Dr Casalis left for Paris yesterday and he is going to cable for us, so I don't suppose it will be long before we go over now. We are all getting tired of the long wait, but the rest before the work is doing us all good....

I hope you are keeping well and that you are not doing too much. If you don't hear from me next week you'll know that we'll have had to leave and are most likely travelling to Cannes. We have to go right through the whole of France.

Love to all at home from

\section{Betty}

'Mary': this is Mary Pearce, now Goulden, who is 93 and lives in Wynberg in Cape Town. She remembers Betty well. The Pearces and the Freunds were good friends. Mrs Pearce visited Metha Freund in 1915 and her sister visited Betty in London just before the Ambulance left for France. The cousin mentioned here was Gerald Giddey of the Transvaal Scottish Regiment who was sent to the hospital in Richmond where he had a foot amputated. He married an English girl, returned to SA where he worked on the ERPM mine till his death. Mary's father was W.H.D. Pearce who took over the well-known shop from his brother F.J. Pearce. Mary's father played a prominent part in the early history of Claremont. He was MPC for Claremont for 20 years and 
was instrumental in getting the Shop-Assistants Act passed whereby working conditions for shop assistants were greatly improved. By 1903 W.H.D. Pearce had shops in Wynberg, Kalk Bay, and Kimberley, as well as the one in Claremont. In 1932 the Cape Times carried an article on him entitled 'The Grand Old Man of Claremont' (30 Sept) and in 1937 a presentation was made to him as 'the Man who has helped to develop Claremont' (Cape Times, 8 January 1937).

The battle referred to here could have been the First Battle of Ypres, which went on for a month. By the end of November there was a continuous fron from Belfort on the Swiss border to the English Channel. In the first five weeks of fighting the combatants on both sides lost more than half a million men.

\section{From London to John Freund, Betty's father}

5 January 1915

\section{My dear Papa,}

I have not heard from you since I arrived in England, but both Mama and Mimie said in their last letters that you were quite well ... Some people think the war here won't last long, but the greater majority think it won't be over till the end of this year, if then. They are all preparing for the Spring now, and yesterday I read an article in the Daily Mail here in which the writer said that Germany had still nearly a million men which she is keeping back to put in the field in the Spring. Day by day you see soldiers leaving for the front and they are all young men. The pity of it all, they all leave homes behind and someone mourns for them. Sunday was a day set apart for prayers for Peace over the whole British Empire. These prayers were written by two Archbishops and they are the first real notes of true Christianity I have heard since the war started ... they prayed most earnestly in a Christian spirit for their Enemies. The churches are so different here - of course all over Europe they are different to the cold and dreary churches they have in South Africa, but then the Dutch have no sense of Beauty -

We are all anxious to be off to the front .... Write soon and tell me how you are.

Your loving daughter

\section{Betty Freund}

A recurring theme of the time was: 'War will be over by Christmas'.

The 'Day of Prayer' Betty mentions here was held on Sunday 3 January 1915. The Times of 4 January had the following report:

'In St. Paul's Cathedral there were three services. Both the morning and afternoon services included the special Collects and other features of the Form of Humble Prayer issued under the authority of the Archbishops of Canterbury and York. At the evening service the preacher was the Archbishop of Canterbury....
'The Archbishop took his text from Phil. iv. 7, "The peace of God, which passeth all understanding, shall keep your hearts and minds throught Christ Jesus".'

The following are two excerpts from this sermon:

¿... We are face to face with definite dangers for those whom we love, and quite possibly for ourselves. They are real and urgent. They mark the gravity of these great days. But to be therefore plunged into gloom is to miss the meaning and character of our Christian calling, which was to fit and arm us for such days as these, not less than for times of quiet....

'... And so, while on these memorable days of an opening year we pray for wisdom and understanding, for counsel and strength, we shall, with equal earnestness, give thanks....

At a special service held at Sandringham Parish Church the Bishop of Norwich said:

'Whatever effort we may make to see the point of view of our opponents, and whatever credit we give to them for being as sincere as ourselves in their prepossessions, yet from our own point of view we cannot pretend that we do not feel ourselves to be fighting on the side of and for the sake of righteousness and honour, truth and freedom. If God and our conscience, that is, the voice of God within, have called upon us to fight manfully, to fight Christianly, and to fight to the end, it would seem out of place to speak of humiliation in this connection....

\section{Letter from Grand Hotel, 12 Boulevard des Capucines, Paris}

15 January 1915

My dear Mama,

We left London Wednesday evening for Southampton. We came over from there by boat to Havre, it took us 6 hours ... and most of us were sea-sick. At Havre we stayed at a beautiful hotel which had been turned into a hospital by the French ....

We came to Paris in the morning and passed through most beautiful country all the way up. We are leaving tonight for Cannes, will only arrive there to-morrow, Saturday eve. or Sunday morning. The trains only run at half-speed now. French men are not very prepossessing-looking. I hope you are well, write and tell me how you are. I gave you our address in my letter from London -

Things are very expensive here, a cup of tea 1/I have just seen the most beautiful roses. It is much warmer than in England and not so dark. Am writing with an awful Hotel pen.

Love to you all from 


\section{From Hotel Beau Rivage, Cannes}

17 January 1915

\section{Dear Mama,}

We arrived here yesterday afternoon after being in the train from Paris for 20 hours ....

\section{(Monday 18th)}

I cant describe Cannes to you, it is all too beautiful, the sea this morning is too lovely, how I wish you could see it all. We are staying in a most beautiful Hotel with a wonderful garden ... our Hotel is not quite ready yet ....

Dr Casalis (Colonel now) could not be sent right to the front, as they are only sending their own military doctors there. I am awfully sorry we wont get very many heavy operations here, but lots of
Medical cases. They say 30 soldiers die here in Cannes a day. The Hotel Carlton ... is run as a Hospital by some French ladies who are not trained. Dr Casalis wants to reduce the death rate as much as possible. Everybody here expects great things from us....

How I wish you could just be here for a week to see it all and enjoy so much beauty ... you'll have to let Papa read all my letters as postage is so expensive...

Your loving daughter

\section{Betty Freund}

* A full biographical sketch re the author of the above article who is a senior lecturer Dept of English, University of Pretoria, appears at the end of part one of the article, in Militaria $15 / 1$ of 1985 